\title{
Saccharomycodes ludwigii, Control and Potential Uses in Winemaking Processes
}

\author{
Ricardo Vejarano \\ Faculty of Engineering, Universidad Privada del Norte (UPN), Av. Del Ejército 920, 13001 Trujillo, Peru; \\ ricardo.vejarano@upn.edu.pe; Tel.: +51-(44)60-6200-4298
}

Received: 25 July 2018; Accepted: 25 August 2018; Published: 27 August 2018

\begin{abstract}
Non-Saccharomyces yeasts are becoming important because most of them are considered as spoilage species in winemaking processes, among them the species Saccharomycodes ludwigii. This species is frequently isolated at the end of the fermentation process and/or during storage of the wine, i.e., it can to grow in the presence of high levels of ethanol. Besides, this species is adaptable to unfavorable conditions such as high concentrations of $\mathrm{SO}_{2}$ and is characterized by its capacity to produce high amounts of undesirable metabolites as acetoin, ethyl acetate or acetic acid. To the present, physical (gamma irradiation and continuous pulsed electric fields), chemical (inhibitory compounds such as chitosan and dimethyl dicarbonate) and biological (antagonistic biocontrol by killer yeasts) treatments have been developed in order to control the growth of this spoilage yeast in wines and other fruit derivatives. Therefore, this review is focused on the most relevant studies conducted to control contamination by S. ludwigii. Moreover, potential applications of S. ludwigii in alternative winemaking techniques, for example for ageing-on-lees and stabilization of red wines, and improvement of aromatic profile are also examined.
\end{abstract}

Keywords: non-Saccharomyces yeast; Saccharomycodes ludwigii; S. ludwigii; spoilage yeasts' control; ageing-on-lees

\section{Introduction}

In addition to spoilage bacteria that cause problems in the wine industry, detection and control of spoilage yeasts are vital [1], especially those capable of growing under conditions of low water activity $\left(A_{W}\right)$ and high ethanol content and acidity as well as in the presence of chemical preservatives [2-4], conditions in which other microorganisms are not completely viable.

Grapes and the presence of vectors (insects) that transport microorganisms to the interior of wineries are considered to be the main sources of contamination [5]. Yeasts such as Dekkera/Brettanomyces spp., Zygosaccharomyces bailii and Saccharomycodes ludwigii are considered detrimental to the winemaking process [4]. The presence of these yeasts is indicated by the appearance of superficial films and the production of gases in stored wine, turbidity, sediments, as well as undesirable odors and flavors [6,7].

\section{Saccharomycodes ludwigii}

$S^{\prime}$ codes ludwigii is known for its ability to contaminate fruit juices and fermented beverages such as wines and cider. Morphologically, it appears as elongated cells with bipolar apiculation (budding yeast) and swelling in the middle (Figure 1), and it presents asexual reproduction by bipolar budding $[8,9]$. 


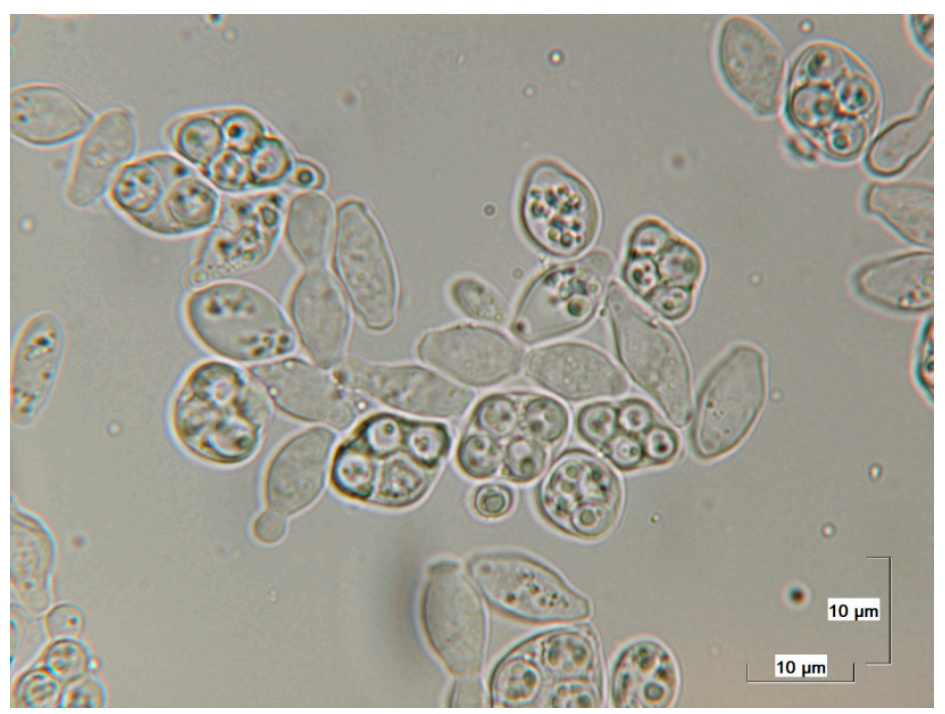

Figure 1. Apiculated cells of Saccharomycodes ludwigii at a magnification of $600 \times$.

$S^{\prime}$ codes ludwigii causes serious problems in the industry due to its high tolerance to sulfur dioxide $\left(\mathrm{SO}_{2}\right)$ [10] and is commonly referred to as the "winemaker's nightmare" due to the difficulty in eradicating it from contaminated environments [11-13]. It has also shown resistance to pressurized carbon dioxide $\left(\mathrm{CO}_{2}\right)$ with the ability to deteriorate carbonated beverages [6]. It has also been isolated from sweet wines, thus demonstrating its tolerance to high sugar levels [3,4]. Together with Z. bailii and some Saccharomyces cerevisiae strains, S'codes ludwigii is among the spoilage species in bottling lines, especially wines, the process of which uses additives such as $\mathrm{SO}_{2}$ or sorbic acid [14].

Regarding its fermentative capacity, $S^{\prime}$ codes ludwigii can produce up to $12 \% v / v$ of ethanol $[2,10,15]$ and acetic acid, in most cases at concentrations $<1.0 \mathrm{~g} / \mathrm{L}$ [2,3]. Some strains have shown acetic acid yields of $0.3-0.5 \mathrm{~g} / \mathrm{L}$, similar to some selected strains of $S$. cerevisiae [10]. In addition, this yeast is characterized by its high production of secondary metabolites, such as isobutanol $(20.0-200 \mathrm{mg} / \mathrm{L})$, amyl alcohol (32.0-58.0 mg/L), isoamyl alcohol (75.0-190 mg/L), acetaldehyde (46.7-124 mg/L), acetoin $(104-478 \mathrm{mg} / \mathrm{L})$ and ethyl acetate $(141-580 \mathrm{mg} / \mathrm{L})[2,3,10,11,16]$, which can confer negative undertones to the wine upon exceeding their respective thresholds of perception. However, some strains have shown high production of metabolites such as succinic acid (up to $1.4 \mathrm{~g} / \mathrm{L}$ ) and glycerol (up to $11.7 \mathrm{~g} / \mathrm{L}$ ) [2,3].

The high yield of isobutanol [11] and acetaldehyde [10] can be considered discriminant characteristics of S'codes ludwigii; however, Romano et al. [11] obtained low yield of acetaldehyde with several strains, in contrast to the high production of this metabolite by $S^{\prime}$ codes ludwigii as reported in the literature. Other differential characteristics of this yeast are its great capacity to release polysaccharides and its high production of ethyl acetate [10].

Regarding its sugar consumption, S'codes ludwigii can ferment glucose, sucrose and raffinose, although it cannot ferment maltose, galactose and lactose [6,17]. It is also capable of assimilating glycerin, cadaverine and ethylamine, although it does not assimilate nitrates [17].

$S^{\prime}$ codes ludwigii has been reported to increase its production of glycerin, acetic acid and ethyl acetate in media with high concentrations of sugar [3], a phenomenon that can be related to the mechanism of adaptation to osmotic stress to prevent dehydration. Glycerin synthesis involves the oxidation of $\mathrm{NADH}$ to $\mathrm{NAD}^{+}$, and acetic acid synthesis allows $\mathrm{NADH}$ to be regenerated [18]. A similar response has been observed in yeasts against toxins, such as the Pichia membranifaciens killer toxin (PMKT) [19], so that the osmophilic media protect the yeasts from the action of the PMKT toxin. 


\subsection{Sources of Contamination by Saccharomycodes ludwigii}

Most spoilage yeasts come directly from the surface of grapes (Figure 2) and of equipment and cellar installations [20]. Commonly, S'codes ludwigii has been isolated in cases of stuck or sluggish fermentations or during storage of wines $[3,7,10,21]$. It has also been detected in fruit juices and their fermented derivatives [9,22], tequila and mezcal [23], in soil samples [24], insects [5] and tree secretions $[8,25,26]$.

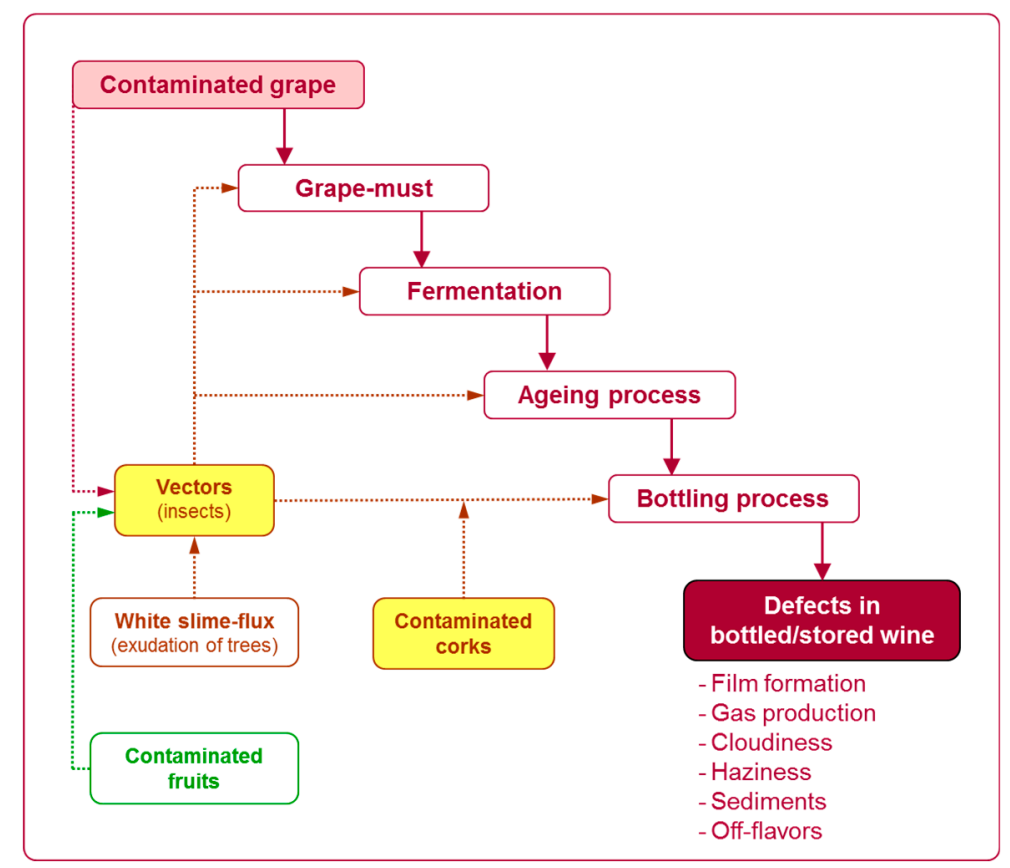

Figure 2. Main sources of Saccharomycodes ludwigii, as a spoilage yeast in wines.

In the case of tree secretions, $S^{\prime}$ codes ludwigii, together with other microorganisms, would be transported from "sick trees" to the wineries by insects [5,6]. Sick specimens of trees such as oak, birch, poplar, beech, willow, maple and ash can produce the so-called "alcoholic flux" or "white slime flux", which is characterized by its high content of microorganisms and its smell of beer, malic ester and vinegar [25]. Cases of contamination by $S^{\prime}$ codes ludwigii have also been reported in corks that were inadequately treated with $\mathrm{SO}_{2}$ before packing [4].

Another source of $S^{\prime}$ codes ludwigii, as well as species such as S. cerevisiae and Z. bailii, is palm sap, from which a fermented drink known as "palm wine" is obtained in Cameroon [26]. S'codes ludwigii is the dominant species at the beginning of the fermentation process, and as the fermentation proceeds, its population decreases in favor of $S$. cerevisiae.

\subsection{Detection of Saccharomycodes ludwigii}

$S^{\prime}$ codes ludwigii has been proven to have a high polluting capacity, starting from only one or two cells per liter [27]. The limitations in its proper detection and control are the same as those in the case of other spoilage yeasts, such as the short incubation periods of traditional methods and the use of media for counting "total molds and yeasts" [4].

Among other alternatives, detection based on biomarkers, such as the low content of long chain fatty acids (C18:2 and C18:3) characteristic of S'codes ludwigii [7], can be applied; however, its application at the industrial level requires access to databases that allow the interpretation of these molecular profiles in real time to take immediate corrective actions. Another alternative is the use of chemical and organoleptic indicators, similar to 4-ethylphenol produced by Dekkera/Brettanomyces 
spp. [28]. Isobutanol, acetaldehyde, ethyl acetate and acetoin can be used as aromatic indicators of $S^{\prime}$ codes ludwigii $[2,3,10,11,16]$.

\subsection{Disadvantages of "Sulfiting" and Resistance of Saccharomycodes ludwigii}

$\mathrm{SO}_{2}$ is generally recognized as a safe additive and is used as an antioxidant and preservative in the control of spoilage bacteria, molds and yeasts. According to Stratford et al. [12], the three forms of $\mathrm{SO}_{2}$ in solution as a function of $\mathrm{pH}$ are called "sulfites"; the molecular form $\left(\mathrm{SO}_{2}\right)$ predominates at $\mathrm{pH}$ values of $<1.80$, the $\mathrm{HSO}_{3}{ }^{-}$form at $\mathrm{pH}$ values of $1.80-7.20$ and the $\mathrm{SO}_{3}{ }^{2-}$ form at $\mathrm{pH}$ values of $>7.20$. Of these, $\mathrm{SO}_{2}$ has the greatest antimicrobial effect [29]. The International Organization of Vine and Wine [30] establishes maximum levels of sulfites according to the type of wine (red, white or rosé), with a higher dose of $\mathrm{SO}_{2}$ at higher levels of reducing sugars. In Europe, the presence of sulfites must be stated on the bottle when they exceed $10 \mathrm{mg} / \mathrm{L}$ (European Union Regulation No. 1991/2004).

Some of the disadvantages of using sulfites are the resistance of $S^{\prime}$ codes ludwigii [12], as well as the dependence of the effect of $\mathrm{SO}_{2}$ on $\mathrm{pH}$, the generation of undesirable odors and flavors and binding of $>50 \%$ of the added dose to certain grape-must/wine molecules [12,31], thus losing its antiseptic and antioxidant activity [1]; therefore, its use in the established doses does not always ensure total protection. In addition, sulfites can generate health problems in consumers, such as headaches, allergic reactions and respiratory difficulties in asthmatic individuals, both in its free and linked form [32,33].

Therefore, there is a growing interest in the search for alternative treatments to $\mathrm{SO}_{2}$, in line with consumers' growing preference for products free of chemical additives [34,35].

Regarding the resistance to $\mathrm{SO}_{2}$, Stratford et al. [12] required doses of up to $7.8 \mathrm{mM}$ of free sulfites to inactivate $S^{\prime}$ codes ludwigii, which is considerably higher than that required to inactivate S. cerevisiae (1.56 mM free sulfites). They also obtained a high yield of acetaldehyde with $S^{\prime}$ codes ludwigii in the presence of $\mathrm{SO}_{2}$. This response would be a defense mechanism, as is the case with other yeasts, through which $\mathrm{SO}_{2}$ joins acetaldehyde and other molecules such as pyruvate and 2-oxoglutarate ("sulfite-binding compounds").

The resistance of glyceraldehyde-3-phosphate dehydrogenase (GPDH), especially that of $S^{\prime}$ codes ludwigii, to sulfites has also been proposed as a defense mechanism, without affecting the production of cellular ATP [12,36]. Likewise, only the $\mathrm{SO}_{2}$ form crosses the cell membrane [37]. S'codes ludwigii has a higher $\mathrm{C} 18: 1$ fatty acid content in its cell membrane [7], which may give greater fluidity to the diffusion of $\mathrm{SO}_{2}$ toward the outside [38] and may palliate its toxic effect. This would add an additional mechanism related to low intracellular $\mathrm{pH}$ in $\mathrm{S}^{\prime}$ codes ludwigii, which would favor $\mathrm{SO}_{2}$ remaining as such, allowing it to flow to the outside without accumulating in the cytoplasm [37].

In Table 1, a summary of studies related to the control of $S^{\prime}$ codes ludwigii in grape-must, wine and fruit juices is presented, which will be described in more detail in the subsequent sections. 
Table 1. Applied treatments for the control of Saccharomycodes ludwigii.

\begin{tabular}{ccc}
\hline Sample & Applied Treatment & Reference \\
\hline & DMDC & {$[31,39]$} \\
Grape must & DMDC $+\mathrm{SO}_{2}$ & {$[39,40]$} \\
& DMDC + sorbic acid & {$[39]$} \\
& Toxin of Pichia anomala WC65 & {$[41]$} \\
Apple juice & Toxin KpKt & {$[42]$} \\
Mango pulp & Biological control: Metschnikowia pulcherrima & {$[43]$} \\
& Chitosan & {$[22]$} \\
Wine & Gamma radiation & {$[44]$} \\
& Gamma radiation + steaming & {$[21]$} \\
& DMDC in red wine & {$[40]$} \\
\hline
\end{tabular}

DMDC: dimethyl dicarbonate. KpKt: Kluyveromyces phaffii killer toxin. PEF: pulsed electric fields.

\section{Control by Chemical Treatments}

\subsection{Dimethyl Dicarbonate}

Dimethyl dicarbonate (DMDC), also known as dimethyl pyrocarbonate, can be used to partially replace and help reduce $\mathrm{SO}_{2}$ doses [31], with the advantage that it does not generate odors or unpleasant flavors in wine [40], even at the maximum dose of $200 \mathrm{mg} / \mathrm{L}$, authorized by the International Organization of Vine and Wine (OIV) [46].

In aqueous solutions, DMDC is rapidly hydrolyzed mainly to $\mathrm{CO}_{2}$ and methanol at concentrations considered to be safe [47], and its hydrolysis rate increases with temperature; for example, at 10, 20 and $30{ }^{\circ} \mathrm{C}$, it is hydrolyzed in 4,2 and $1 \mathrm{~h}$, respectively [40]. Its rapid hydrolysis gives it effectiveness as an oenological additive, capable of disinfecting grape-must/wine without leaving toxic residues, unlike its "cousin" diethyl dicarbonate (DEDC), which generates ethyl carbamate, having a carcinogenic potential [48].

The antimicrobial activity of DMDC is favored by low microbial population, low $\mathrm{pH}$ values, high ethanol and $\mathrm{SO}_{2}$ contents and temperatures of $20-30^{\circ} \mathrm{C}$. Higher doses are needed to sterilize grape-musts and dealcoholized wines than wines [21,39,40]; DMDC has a greater effect on yeasts than on bacteria [21,31] possibly due to the denaturation of the enzymes GPDH and alcohol dehydrogenase [49].

DMDC acts quickly after dosing, although its period of action is short, unlike $\mathrm{SO}_{2}$, which acts progressively and action is durable; thus, the effectiveness of both preservatives lies in their simultaneous use [50]. Low $\mathrm{pH}$ values, which would allow for a high molecular $\mathrm{SO}_{2}$ concentration, are desirable $[29,50]$.

Terrell et al. [39] evaluated the antimicrobial capacity of $0.2,0.4$ and $0.8 \mathrm{mM}$ of potassium metabisulfite $\left(\mathrm{as}_{2}\right)$, potassium sorbate and DMDC in fermentation with $\mathrm{S}$. cerevisiae at different levels of inoculum $(2,200$ and $20,000 \mathrm{CFU} / \mathrm{mL})$ and temperatures of 21 and $31^{\circ} \mathrm{C}$. The pure DMDC showed an inhibitory effect, and its combinations showed an inhibitory effect to a lesser extent. At $31{ }^{\circ} \mathrm{C}$, the effectiveness of DMDC and its combinations at a dose of $0.8 \mathrm{mM}$ at all inoculum levels increased. No significant differences were observed between $\mathrm{SO}_{2}$, sorbate and $\mathrm{SO}_{2}+$ sorbate at different temperatures and at different preservative concentrations, at all inoculum levels.

Threlfall and Morris [40] evaluated the growth and fermentation capacity of Saccharomyces bayanus in grape-must and semi-sweet wine at $20^{\circ} \mathrm{C}$ and at different $\mathrm{pH}$ values. Certain combinations of $\mathrm{SO}_{2}$ and DMDC were only effective at $\mathrm{pH}$ values of 3.0 and 3.2. The minimum doses to completely inhibit microbial growth and fermentation were $200 \mathrm{mg} / \mathrm{L}$ of DMDC in grape-must and $50 \mathrm{mg} / \mathrm{L}$ of $\mathrm{SO}_{2}$ or $100 \mathrm{mg} / \mathrm{L}$ of DMDC in semi-sweet wine, whereas the most effective minimum combinations were 
$50 \mathrm{mg} / \mathrm{L}$ of $\mathrm{SO}_{2}+100 \mathrm{mg} / \mathrm{L}$ of DMDC in grape-must and $10 \mathrm{mg} / \mathrm{L}$ of $\mathrm{SO}_{2}+50 \mathrm{mg} / \mathrm{L}$ of DMDC in semi-sweet wine at any $\mathrm{pH}$ value.

On the other hand, Delfini et al. [31] evaluated the inhibitory effect of DMDC (50-10,000 mg/L) in fermentation with grape-must. The dose of $400 \mathrm{mg} / \mathrm{L}$ was sufficient to inhibit $S^{\prime}$ codes ludwigii and other species, such as Hanseniaspora osmophila, S. pombe and Z. bailii. Higher doses were required to inhibit bacteria such as Acetobacter aceti and Lactobacillus sp. (1000 and $500 \mathrm{mg} / \mathrm{L}$, respectively). The authors also concluded that in grape-must treated with $200 \mathrm{mg} / \mathrm{L}$ of DMDC (maximum authorized dose), it is recommended to inoculate with $S$. cerevisiae for at least $12 \mathrm{~h}$ after dosing to ensure complete hydrolysis and antimicrobial action.

A dose of $200 \mathrm{mg} / \mathrm{L}$ would be recommended to confer prolonged stability [21,50]. However, DMDC cannot be used to replace $\mathrm{SO}_{2}$, so its use can only help minimize the doses of the latter [40]. Therefore, during barrel aging, the addition combined with $\mathrm{SO}_{2}$ would be the best alternative, considering that $\mathrm{SO}_{2}$, in addition to microbicide acts as an antioxidant, and thus, the loss of color in red wine in the presence of pure DMDC due to oxidation is avoided [50].

Regarding the rapid hydrolysis of DMDC during barrel aging, periodic dosages of low concentrations $(25 \mathrm{mg} / \mathrm{L})$ can help maintain the microbiological quality of wine and lower the doses of $\mathrm{SO}_{2}$. However, it should be emphasized that the maximum dose allowed by the OIV $(200 \mathrm{mg} / \mathrm{L})$ is more effective against yeast than against bacteria, especially those producing lactic acid and acetic acid, requiring $>500 \mathrm{mg} / \mathrm{L}$ doses of DMDC [21,31].

\subsection{Chitosan}

Chitosan is a deacetylated derivative of chitin, which is a part of the structure of many organisms. Chitosan is considered to act as a chelator of minerals such as Ca and Fe from the fermentation medium, affecting their availability for microbial growth [51,52]. The loss of protein compounds and UV radiation-absorbing material from the cell membrane has also been proposed [53,54].

Due to its polycationic nature (high presence of $\mathrm{NH}_{2}{ }^{+}$groups), it can interact with negatively-charged groups present in cell surface molecules, such as proteins, anionic polysaccharides, fatty acids and phospholipids, among others, affecting the cell functions and transport of essential nutrients to the inside of the yeast $[55,56]$. The most commonly-used chemical forms include chitosan glutamate and chitosan lactate [22], the latter having an effect on S. cerevisiae at a concentration of $1.0 \mathrm{~g} / \mathrm{L}$ [57].

Roller and Covill [22] evaluated the effectiveness of different doses of chitosan in apple juice sterilized by ultra-high temperature (UHT) and without additives, against a strain of $S^{\prime}$ codes ludwigii (isolated from contaminated cider). Total inhibition was achieved at a dose of $5.0 \mathrm{~g} / \mathrm{L}$ of chitosan, whereas a dose of $1.0 \mathrm{~g} / \mathrm{L}$ only induced a delay in the start of fermentation, without affecting the end of the fermentation process.

Evidently, there is little literature regarding the application of chitosan in the control of $S^{\prime}$ codes ludwigii, which leaves open the possibility of future research to better understand the potential of this polymer in controlling this yeast.

\section{Biological Controllers}

Another alternative is biological controllers, specifically the so-called killer yeasts, which have an antimicrobial effect on S'codes ludwigii, for example some species of Pichia, Kluyveromyces and Metschnikowia.

$S^{\prime}$ codes ludwigii has shown sensitivity to the microbial toxin produced by Pichia anomala WC65. Sawant et al. [41] observed good stability of this toxin at $\mathrm{pH}$ values of 2.0-5.0, the usual range in wines. At high concentrations, however, the toxin showed a tendency to aggregate, with loss of activity against $S^{\prime}$ codes ludwigii and other yeasts and blocking of recognition sites being the possible cause for this loss of activity [58]. Therefore, low concentrations could be useful for treatment, although no more studies have been reported. 
Another genus, the toxin of which has antimicrobial activity, is Kluyveromyces. Palpacelli et al. [42] evaluated the killer activity of the species Kluyveromyces phaffii, Kluyveromyces lactis and Kluyveromyces vanudenii. All showed antimicrobial activity against $S^{\prime}$ codes ludwigii. K. phaffii also showed activity against Kloeckera apiculata and Zygosaccharomyces rouxii. According to the authors, the toxin involved is Kluyveromyces phaffii killer toxin (KpKt). Nevertheless, the authors pointed out the need to apply the procedure at the fermentation level, considering that the study was conducted at the laboratory level (plate cultures).

The yeast Metschnikowia pulcherrima also has antimicrobial activity and has been used as a biological controller of fungi that cause diseases in fruits [59]. This yeast can grow in mature and overgrown grapes, botrytized grapes and grapes used to make so-called ice wines [60]. The activity of M. pulcherrima, in addition to the killer phenomenon [61], would be mainly related to the production of the pulcherrimin pigment by the chelation of Fe in the medium [62], thus decreasing the availability of this mineral for the development of other microorganisms.

Oro et al. [43] evaluated the antimicrobial activity of M. pulcherrima against different yeasts and did not observe any effect on S. cerevisiae, but did see an effect on Pichia, Brettanomyces/Dekkera, Hanseniaspora and especially on S'codes ludwigii.

An interesting alternative for controlling spoilage yeasts during the fermentation process could be the use of mixed inocula with S. cerevisiae, which is not affected by M. pulcherrima by regulating the absence of Fe in the fermentative medium [63], in addition to taking advantage of other benefits of M. pulcherrima, such as its ability to produce aromatic compounds [64].

Although the literature does not report any cases, the potential killer of other yeasts could also be studied for the control of S'codes ludwigii; for example, Candida pyralidae, producer of the C. pyralidae killer toxin (CpKT), with activity against Brettanomyces bruxellensis. This toxin has shown stability at $\mathrm{pH}$ values of $3.5-4.5$ and at temperatures of $15-25^{\circ} \mathrm{C}$, i.e., it is compatible with the winemaking conditions and is not affected by the sugar and ethanol levels present in grape-must/wine. In addition, it has not shown effects on S. cerevisiae or on lactic acid bacteria, which would not affect the normal red winemaking process [65]. In the same way, in winemaking conditions ( $\mathrm{pH}$ values of 3.0-4.5 and at temperatures of $15-25^{\circ} \mathrm{C}$ ), Ustilago maydis fungus has shown killer activity against $B$. bruxellensis [66].

Another potential killer yeast against $S^{\prime}$ codes ludwigii is P. membranifaciens, the PMKT toxin of which has shown antifungal activity, with mechanisms that include the alteration of plasma membrane permeability, alteration of cell cycle and induction of cellular apoptosis $[19,67]$. S. cerevisiae has not shown sensitivity to PMKT, but Z. rouxii has shown high sensitivity, as well as Z. bailii, to a lesser degree [68].

In addition, PMKT can synergistically increase the effect of $\mathrm{SO}_{2}$. In this regard, Alonso et al. [68] evaluated combinations of PMKT and $\mathrm{SO}_{2}$ in a medium with high glucose content $(60 \% \mathrm{w} / \mathrm{v})$, showing an inhibitory effect against $\mathrm{Z}$. rouxii, although the mechanism of synergistic action $\mathrm{PMKT}^{-\mathrm{SO}_{2}}$ is not fully understood. Pure $\mathrm{SO}_{2}$ showed no inhibitory effect. Therefore, PMKT could also be used in the control of S'codes ludwigii, considering that it shares similar characteristics with Zygosaccharomyces, such as the capacity to grow in media with high acidity and low $\mathrm{A}_{W}$ and resistance to osmotic stress and to $\mathrm{SO}_{2}$, in addition to contaminating concentrated grape-musts, sweet wines and other wines with high residual sugar content $[3,4]$.

Despite the previously-described studies, several killer toxins from Saccharomyces and non-Saccharomyces yeasts have not yet been characterized. Therefore, further studies are needed in order to identify their genetic origin, mode of action and how to employ them at the industrial level in the control of spoilage yeast, especially $S^{\prime}$ codes ludwigii.

Finally, another interesting strategy to reduce or prevent both the growth of $S^{\prime}$ codes ludwigii and its production of undesirable metabolites in the wine could be the use of starter cultures of yeasts and lactic acid bacteria, as biocontrol agents during alcoholic and malolactic fermentations, similarly to biocontrol processes tested in B. bruxellensis [69]. This strategy could ensure a fast and complete fermentation, limiting the available nutrients for growing of spoilage yeasts. 


\section{Control by Physical Treatments}

Out of the various available options, only pulsed electric fields (PEFs) and gamma radiation $(\gamma)$ have been studied in specific cases with $S^{\prime}$ codes ludwigii. Other technologies, such as high hydrostatic pressure (HHP), ultrasound (US), pulsed light and e-beam radiation, have been applied to inactivate and reduce total populations of yeasts and bacteria in grape-musts and wines [70].

\subsection{Pulsed Electric Fields}

PEFs cause cell damage through a mechanism related to electroporation or electrical disruption of the membrane, altering the permeability [71]; thus, yeasts become more sensitive (larger size and oval shape) than bacteria $[45,72,73]$ and without the disadvantage of modifying the physicochemical properties and sensorial attributes of grape-must/wine [72,74].

The effectiveness of PEFs varies depending on ethanol content, acidity and temperature, among other factors. Z. bailii has shown greater sensitivity in the presence of ethanol [75]. S. cerevisiae in a treatment at $45 \mathrm{kV} / \mathrm{cm}, 46.3$ pulses and $70 \mu$ in beer with alcoholic degrees of $0 \%, 5.2 \%$ and $7.0 \%$ showed logarithmic reductions of $0.2,0.7$ and 2.2, respectively [76]. Even in the last study, a greater effect was observed at $40-50{ }^{\circ} \mathrm{C}$ during treatments in the order of micro- to milli-seconds. Similar results were obtained by Timmermans et al. [73]. However, the optimization of the applicable dose and temperature is required for the purposes of seeking the industrial applicability of PEF as some constituents of grape-must/wine are thermosensitive.

On the other hand, Puértolas et al. [72] managed to reduce the contaminating flora by $99 \%$ in grape-must and wine at $186 \mathrm{~kJ} / \mathrm{kg}$ and $29.0 \mathrm{kV} / \mathrm{cm}$, with greater effectiveness on yeast. There were no significant changes in the color and odor of must and wine treated, even at high doses of PEF. Likewise, all microorganisms were more sensitive in wine than in must, an effect that was attributed to the ethanol content of wine, in accordance with previous results $[75,76]$.

Of the limited experience with the specific application of PEF with S'codes ludwigii, only González-Arenzana et al. [45] evaluated a semi-industrial continuous flow system (13.75 L/h) for the control of artificially-contaminated wine, $S^{\prime}$ codes ludwigii being the microorganism that showed greater sensitivity to a specific energy of $60 \mathrm{~kJ} / \mathrm{kg}(103 \mu \mathrm{s})$.

In this sense, PEF could allow for a significant reduction in the doses of $\mathrm{SO}_{2}$ through combined treatment, or in the best of cases, to dispense with its use. In spite of the scarce background, PEF would be an interesting alternative for the control of $S^{\prime}$ codes ludwigii considering its elongated cell morphology [72]. However, one aspect to be taken into account is the tolerance to ethanol shown by $S^{\prime}$ codes ludwigii; therefore, the study of the combined effect of different treatments could better elucidate control pathways during the fermentation process.

\subsection{Gamma Radiation}

Ionizing radiation, or in combination with conventional chemical and thermal treatments, has been proposed as a replacement alternative. Youssef et al. [44] studied the effect of a combined treatment with steam and $\gamma$ radiation on the microbiological quality in mango pulp, obtaining a considerable increase in the shelf-life of the product (270 days) compared with irradiated samples without pretreatment with steam (90 days) and with controls without any treatment (15 days). No defects of a chemical, rheological or sensory nature were found.

In addition, six strains of $S^{\prime}$ codes ludwigii were isolated from the untreated pulp, which were inhibited in a medium based on mango pulp at a $\mathrm{D}_{10}$-dose of $2.23 \mathrm{kGy}$ of $\gamma$ radiation $\left(\mathrm{D}_{10}\right.$ : dose necessary to inactivate $90 \%$ of the microbial population), whereas a greater effect was observed in saline solution $\left(\mathrm{D}_{10}=1.75 \mathrm{kGy}\right)$. This indicates that the effect of the $\gamma$ radiation is influenced by interactions with solids in the medium, which make higher doses of radiation necessary. Therefore, more studies will contribute to improving its application, without producing chemical and sensory changes. 


\section{Other Applications of Saccharomycodes ludwigii}

Traditionally, S'codes ludwigii and other non-Saccharomyces have been considered spoilage yeasts, which is a concept that has changed in recent decades thanks to several works that demonstrate their advantages in the production of wine and other beverages.

\subsection{Aromatic Profile Improvement in Wines}

It has been noted that most of the secondary metabolites produced by pure cultures of non-Saccharomyces do not reach the thresholds of perception when they are made in mixed fermentation with $S$. cerevisiae, since the latter can modulate the metabolism of the former [10,77]. Although $S^{\prime}$ codes ludwigii produces high levels of ethyl acetate and acetic acid, it is possible to modulate this production in mixed cultures, in addition to improving the yield of esters with a positive impact on the wine's aromatic profile.

One case is the Sd64 strain studied by Domizio et al. [10], which in mixed cultures with S. cerevisiae (ratio $10^{3}: 10^{7}$ cells $/ \mathrm{mL}$ ), increased the production of glycerin (up to $21.8 \%$ ), isoamyl acetate (up to $20.8 \%$ ) and 2-phenylethanol (>200\%) compared with a pure culture of $S$. cerevisiae, besides producing low volatile acidity $(0.32 \mathrm{~g} / \mathrm{L})$, lower than other non-Saccharomyces and the pure culture of $S$. cerevisiae.

However, in mixed culture, high levels of acetaldehyde (up to 33\% higher) and ethyl acetate (up to 10-times higher) were also obtained compared with the pure culture of S. cerevisiae, which could be improved with the selection of strains with low production of these metabolites and with the optimization of fermentative parameters that regulate their production. Granchi et al. [3] obtained a lower yield of acetaldehyde, acetoin and ethyl acetate at $25^{\circ} \mathrm{C}$, when compared with that obtained during fermentation at $15{ }^{\circ} \mathrm{C}$. Conditions also compatible with the $\beta$-glucosidase activity of some strains of $S^{\prime}$ codes ludwigii, $46 \%$ higher than $S$. cerevisiae at $30{ }^{\circ} \mathrm{C}$ [78], favor the release of aromatic compounds from non-aromatic precursors of grapes [79,80], thus improving the wine's aroma. Of course, this improvement would be advisable only in white wines, since $\beta$-glucosidase or anthocyanase generates the hydrolysis of anthocyanins [81], so that its applicability would not be viable in red wines due to the loss of color.

\subsection{Reduction of Alcohol Content in Wine}

High temperatures in vineyards induce changes in the chemical composition of grapes, mainly an increase in sugar and decrease in acids and anthocyanins, which results in wines with a higher concentration of ethanol and alteration in the mouthfeel, flavor and aroma, or even an increase in the sensation of astringency, bitterness and roughness [82], to which we must add the consequences of high doses of ethanol on the consumer's health.

$S^{\prime}$ codes ludwigii can lower the production of ethanol in mixed cultures with S. cerevisiae, as obtained by Domizio et al. [10] with the Sd64 strain (previously mentioned), with which they achieved a reduction in alcoholic degree of up to $1.74 \% v / v$ in mixed culture compared with the pure culture of S. cerevisiae. Therefore, $S^{\prime}$ codes ludwigii can also be considered as a potential yeast to lower the alcoholic degree in mixed fermentations, a field not studied so far.

\subsection{Release of Polysaccharides in Red Wines}

Several studies have demonstrated the feasibility of using $S^{\prime}$ codes ludwigii for the release of polysaccharides in wine not only in the traditional aging-on-lees (AOL), as a result of cellular autolysis $[83,84]$, but also during growth and alcoholic fermentation $[10,15,85]$ due to the controlled hydrolysis of cell walls ( $\beta$-glucanase activity) to allow cell budding [86].

The yeast $S^{\prime}$ codes ludwigii has shown a high capacity to release polysaccharides during the fermentation process - up to $300 \%$ more than S. cerevisiae $[10,15]$ - while rates of release during AOL are $>200 \%$ compared with $S$. cerevisiae $[84,85]$. 
The most abundant polysaccharides are the mannoproteins (Table 2), located in the outer layer of the cell wall, linked by $\beta-1,6$ glucan, $\beta-1,3$ glucan and chitin chains [84,87]. Generally speaking, they contain $85 \%-90 \%$ of carbohydrates, mainly mannose, and $10 \%-15 \%$ of proteins $[84,85,87]$.

Table 2. Composition of cell walls of Saccharomycodes ludwigii, Schizosaccharomyces pombe and Saccharomyces cerevisiae.

\begin{tabular}{ccccc}
\hline Component (\%) & S'codes ludwigii & S. pombe & S. cerevisiae & Reference \\
\hline Proteins & 12 & 11 & $24^{*}$ & \\
Mannose & 93 & 55 & $88^{*}$ & {$[85]$} \\
Glucose & 7 & 22 & $12^{*}$ & \\
Galactose & - & 23 & - & \\
$\alpha(1-3)$ glucan & & Yes & No & \\
$\beta(1-3)$ glucan & & Yes & Yes & {$[84]^{* *}$} \\
$\beta(1-6)$ glucan & & Yes & Yes & \\
Chitin (\% of dry weight) & & 0.5 & 0.1 & \\
\hline
\end{tabular}

$\left.{ }^{*}\right)$ Average for three strains. $\left({ }^{* *}\right)$ Not reported for $S^{\prime}$ codes ludwigii.

Polysaccharides, especially in red wines, can improve the mouthfullness and body [88], sweetness and roundness [89], aromatic persistence [90], protein and tartaric stability [91,92], interaction with tannins and reduction of astringency [93] and protection of phenolic compounds against oxidation, making it possible to maintain antioxidant and anti-inflammatory capacity [94].

Polysaccharides also interact with tertiary aromatic compounds [95], which may confer a lower perception of wood aromas in long-aged wines, in addition to stimulating the malolactic fermentation [96], as well as improving the quality of foam in sparkling wines [97] and adsorbing undesirable compounds such as ochratoxin A [98], the presence of which in wine leads to risks to the consumer's health [99].

Palomero et al. [84] obtained a high release of polysaccharides by S'codes ludwigii (110.51 mg/L) and by S. pombe (103.61 mg/L), with respect to S. cerevisiae $(36.65 \mathrm{mg} / \mathrm{L})$, in a hydro-alcoholic medium. In the case of Saccharomycodes and Schizosaccharomyces, polysaccharides were of a larger molecular size, with a potential positive impact on the wine's palatability. These yeasts' high capacity for releasing polysaccharides is related to the chemical composition and structure of their cell walls (Table 2), mainly glucans and mannoproteins [85].

Likewise, Palomero et al. [84] evaluated the effect of lees in red wine (Garnacha), observing a loss of color due to the weak and reversible interaction between monomer anthocyanins and polysaccharides [100]. Lower loss was observed in pyranoanthocyanins due to the presence of the fourth heteroaromatic ring in its structure [101]. However, the loss of color was lower with $S^{\prime}$ codes ludwigii and S. pombe than with S. cerevisiae.

No significant effect was observed on the volatile fraction, whereas the sensory analysis in the wine treated with lees from $S^{\prime}$ codes ludwigii showed low astringency and bitterness and greater body. However, with this yeast, the perception of the reduction aroma was high, which indicates the need for more work in the selection of strains that confer this characteristic to the treated wine to a lesser extent.

\subsection{Combined Treatments: Aging-on-Lees with Ultrasound}

The coupling of AOL with US is possible because of the cavitation generated in the cell wall by the creation of localized areas with high temperature (up to $5000^{\circ} \mathrm{C}$ ) and high pressure (up to $50,000 \mathrm{kPa})$ [102], in addition to the formation of hydroxyl radicals $(\mathrm{OH})$ that act on the cell wall altered by US waves [103], thus improving the release of polysaccharides.

A research work was conducted on this topic by Kulkarni et al. [83] with S'codes ludwigii, S. pombe, M. pulcherrima, S. cerevisiae and other yeasts in a hydro-alcoholic medium (seven weeks of AOL at $23^{\circ} \mathrm{C}$, applying US at a dose of $50 \mathrm{kHz}$ for $10 \mathrm{~min}$ a day). $\mathrm{S}^{\prime}$ codes ludwigii showed a high rate of release of polysaccharides from the third week around $460 \mathrm{mg} / \mathrm{L}$. 
The authors also applied AOL in red wine, observing a decrease in the anthocyanin content, without affecting the stability of pyranoanthocyanins (vitisins and vinylphenols), in accordance with Morata et al. [101] and Palomero et al. [84], especially with the lees of $S^{\prime}$ codes ludwigii. A decrease in the content of proanthocyanidins was also observed, particularly with the lees of $S^{\prime}$ codes ludwigii, contributing to a decrease in the astringency and bitterness of wine (sensory analysis). Regarding aroma, esters were the main group released, especially ethyl lactate, which could be related to the esterase activity during autolysis.

Finally, AOL implies economic impacts due to the investment necessary to store wines in wine cellars, as well as the potential risk of organoleptic and microbiological alterations in these wines. It is thus necessary to optimize the time and conditions under which AOL is carried out in addition to optimizing the time and intensity of US doses, which in addition to accelerating the process, minimizes the degradation of polysaccharides by the action of US waves [104].

\subsection{Non-Wine Fermentations}

Another interesting alternative for the use of S'codes ludwigii is the elaboration of "fruit wines", in which the high production of aromatic compounds and organic acids can be exploited.

This type of drink is traditionally made with a poor aromatic profile in different parts of the world, mainly because $S$. cerevisiae is used $[105,106]$. Mixed or sequential fermentations could contribute to improving the sensory profile of these beverages, which constitutes an opportunity for the use of $S^{\prime}$ codes ludwigii due to its high production of ethyl acetate, isoamyl acetate and amyl, isoamyl or 2-phenylethyl alcohols $[10,78]$.

\section{Future Perspectives}

\subsection{Adaptation to Harsh Conditions}

It is known that the most studied spoilage yeast is B. bruxellensis, which can be used as a reference to know how much progress has been made and what is possible to improve, allowing the design of effective strategies for spoilage yeast control in wines. Like S'codes ludwigii, B. bruxellensis is capable of surviving and proliferating after alcoholic fermentation is completed [107], even in the presence of $\mathrm{SO}_{2}[108]$.

According to Smith and Divol [109], the factors that allow these spoilage yeasts to be better adapted to unfavorable environments could either be internal (genotypic) or external (nutritional, phenotypic) in nature or both. In this regard, many studies have been performed in order to investigate genetic bases that allow these yeasts to adapt to unfavorable conditions in which other microorganisms are not completely viable, for example high ethanol levels. B. bruxellensis is well adapted to these conditions including its ability to utilize ethanol as a carbon source [110].

On the other hand, to control the proliferation of most of the spoilage yeasts, $\mathrm{SO}_{2}$ is commonly employed, and many studies have been carried out, especially with B. bruxellensis, in order to explore the relationship between $\mathrm{SO}_{2}$ tolerance and genotype. The identification of susceptible or resistant strains to sulfite could help to develop appropriate antimicrobial techniques and efficient spoilage prevention [111]. Capozzi et al. [112] observed the expression of genes involved in carbohydrate metabolism and encoding heat shock proteins, as well as enriched categories including amino acid transport and transporter activity in the presence of $\mathrm{SO}_{2}$. Moreover, geographical origin has shown a significant influence on the biodiversity of spoilage yeast such as $B$. bruxellensis, displaying variation in tolerance to $\mathrm{SO}_{2}$ [113].

Evidently, there is little literature regarding the genotypic and phenotypic characterization of $S^{\prime}$ codes ludwigii, which would lead to better understanding of its mechanisms of adaptation to unfavorable conditions. This aspect leaves open the possibility of future research to better design strategies for effective control of this yeast in winemaking processes. 


\subsection{Emerging Technologies for Controlling S'codes ludwigii}

Emerging technologies, such as HHP and PEF, are interesting alternatives to reduce the doses of antimicrobial agents and antioxidants such as $\mathrm{SO}_{2}$ [114], especially in red wines, which are less susceptible to oxidation than white wines. It is also possible to produce $\mathrm{SO}_{2}$-free red wines by applying UV or e-beam irradiation if hygienic conditions during the process are adequate [70], allowing, among other advantages, for the proper implantation of starter cultures during fermentation, apart from contributing to improving the extraction of phenolic and aromatic compounds.

However, the scaling up of technologies such as PEF at the industrial level is still a pending issue, since most studies have been carried out with small sample volumes and in static systems [115] and occasionally in continuous flow systems at the laboratory level [116]; therefore, it is necessary to conduct more studies that allow for its application in large volumes and in continuous flow systems to implement this technology in the winery, such as the one developed by González-Arenzana et al. [45].

On the other hand, the antimicrobial effect of radiation can be altered due to its interactions with the components of food samples, as observed by Youssef et al. [44], requiring a greater dose of gamma radiation to reduce (by $90 \%$ ) the population of $S^{\prime}$ codes ludwigii in mango pulp (2.23 kGy) compared to a saline solution (1.75 kGy). No studies have been reported (review in ScienceDirect) on the application of this radiation in grape-must.

\subsection{Considerations about Chemical Preservatives}

An important point made by Roller and Covill [22] is the need to evaluate the effect of parameters such as $\mathrm{pH}$, temperature, yeast strains, presence of other preservatives and food composition on the microbicidal capacity of potential preservatives such as chitosan. Most background data show that chitosan has been evaluated in media such as distilled water or phosphate buffer, and the control of $S^{\prime}$ codes ludwigii in fruit juices, especially grape-must, has been little studied; therefore, their behavior is not clear in these types of matrices. Besides, an important background is that chitosan has shown activity against Brettanomyces bruxellensis [117].

In the same vein, a lower antimicrobial effect on $S$. cerevisiae was seen in grape-must than in a synthetic medium at equal doses of DMDC [31]. The authors considered a possible interaction between DMDC and some grape-must/wine compounds, for example with coloring substances. Previously, a significant decrease in the content of ascorbic acid, amino acids, fructose, glucose, lycopene and $\alpha$-carotene was observed in the presence of DMDC in tomato juice [118]. These possible interactions between DMDC and grape-must/wine components merit further investigation due to their possible technological consequences for wine.

Regarding the hydrolysis of DMDC, the production of methyl carbamate has been detected as a result of its reaction with ammonium, amino acids, polyphenols and organic acids present in grape-must/wine, as well as the formation of other metabolites due to its reaction with the higher alcohol content of wine [47]. Therefore, these interactions must be studied in more detail to verify their potential impacts on the quality of the treated grape-must/wine.

Moreover, the maximum allowed dose of DMDC is $200 \mathrm{mg} / \mathrm{L}$ [46], and its complete hydrolysis yields approximately $96 \mathrm{mg}$ of methanol. Although this concentration of methanol is lower than the maximum allowed, $400 \mathrm{mg} / \mathrm{L}$ for red wines and $250 \mathrm{mg} / \mathrm{L}$ for white and rosé wines [30], the presence of endogenous methanol in wine could increase its concentration to toxic levels [119]. Therefore, the search for alternatives that lower the doses of DMDC becomes of special interest, for example its combination with PEF or gamma radiation, with proven efficacy against S'codes ludwigii [44,45].

On the other hand, although the literature does not report previous cases with S'codes ludwigii, treatments with gaseous ozone [120] have shown effectiveness to reduce the concentration of ethylphenols in the wine and a partial reduction of B. bruxellensis cells, considered among the most common spoilage yeasts in winemaking processes [4]. 


\subsection{Selection of S'codes ludwigii Strains with Differentiated Characteristics}

Studies of mixed fermentations between $S^{\prime}$ codes ludwigii and S. cerevisiae mention the modulation of the fermentative metabolism between both yeasts, which would have advantages such as a decrease in the alcohol content, an increase in aromatic compounds and a greater release of polysaccharides $[10,84]$.

Most strains studied have shown a high production of acetoin and ethyl acetate. This indicates the need to select strains of $S^{\prime}$ codes ludwigii with low production of these metabolites, which also contributes to an increase in the levels of desirable metabolites, such as isoamyl acetate (banana flavor) and 2-phenylethanol (rose flavor). Likewise, it would be interesting to evaluate the impact of these strains in co-cultures with $S$. cerevisiae $[10,78]$ on the aromatic profile of wines.

Other aspects that require further study are related to the application of $S^{\prime}$ codes ludwigii in AOL, for example, the search for strains with low pigment adsorption [95] and low expression of anthocyanin activity (anthocyanin- $\beta$-glucosidase) causing the hydrolysis of anthocyanins, given that a high expression of this activity in some strains of $S^{\prime}$ codes ludwigii has been reported $[79,80]$. It is also necessary to study the capacity of $S^{\prime}$ codes ludwigii to produce pyranoanthocyanins (vitisins and vinylphenols), which are more stable than monomer anthocyanins in facing the degradation caused by anthocyanase activity [81], thus minimizing the loss of color during AOL in red wines.

Other aspects to be addressed in future studies with $S^{\prime}$ codes ludwigii, given their high release of polysaccharides, are:

The impact of mannose, glucose and protein content of polysaccharides on the wine quality, only studied so far in model media [121].

The use of $S^{\prime}$ codes ludwigii for the exogenous production of polysaccharides, which can be added to wine during AOL [122]. Of course, it is necessary to search for suitable strains, for example those with a low contribution to the reduction of aromas [84].

\subsection{Production of Other Fermented Beverages}

Another potential industrial application of $S^{\prime}$ codes ludwigii is the production of fermented beverages from other fruits, for example drinks with a higher content of acidity for summer and those with more intense fruity profiles, as demonstrated by Romano et al. [11] with the S81 strain.

Likewise, the high $\beta$-glucosidase activity shown by some strains of $S^{\prime}$ codes ludwigii [78] can be used to improve the varietal aromatic profile, given that this enzyme releases aromatic compounds from glycosylated non-aromatic precursors $[79,80]$.

\section{Conclusions}

$S^{\prime}$ codes ludwigii is a yeast commonly considered as a wine contaminant due to its high production of ethyl acetate, acetoin or acetaldehyde, with negative effects on the sensory profile at levels above its perception threshold. Traditionally, the control of this and other yeasts is carried out with $\mathrm{SO}_{2}$, which, however, at the high doses often required, causes health problems and defects in wine that lead to rejection by the consumer. Among the possible alternatives to $\mathrm{SO}_{2}$, most have been studied for the control of total microbial populations, and not specifically for $S^{\prime}$ codes ludwigii. Of the few studies available, most have been conducted at the laboratory level, which include, for example, physical treatments such as with PEFs and gamma radiation, which still need improvement. Of the chemical treatments available, DMDC, despite being authorized by the OIV, is limited by its rapid hydrolysis and its lack of antioxidant activity, which makes its application in combination with $\mathrm{SO}_{2}$ necessary. Another alternative is chitosan; however, no applications have been reported in grape-musts. Biological control can also be applied, taking advantage of the killer activity of some strains on S'codes ludwigii, an alternative that also requires further studies for its possible scaling at an industrial level.

On the other hand, $S^{\prime}$ codes ludwigii has potential applications in winemaking due to the ability of some strains to reduce the alcoholic degree and volatile acidity, as well as the high production 
of glycerin, isoamyl acetate, 2-phenylethanol and polysaccharides and its $\beta$-glucosidase activity to improve the varietal aroma in white wines. These are considerations that open up new research possibilities without forgetting the potential of $S^{\prime}$ codes ludwigii in the cider and beer brewing industries, to which it would bring many benefits; however, this is not the subject of this review.

Funding: This research received no external funding.

Acknowledgments: Thanks to the National Direction for Research and Development of the Universidad Privada del Norte (UPN) for the financial support in the translation of the manuscript.

Conflicts of Interest: The author declares no conflict of interest.

\section{References}

1. Ribéreau-Gayon, P.; Dubourdieu, D.; Donèche, B.; Lonvaud, A. The Microbiology of Wine and Vinification. In Handbook of Enology, 2nd ed.; John Wiley and Sons Ltd.: Chichester, UK, 2006; Volume 1, pp. 193-221. ISBN 978-0-470-01034-1.

2. Ciani, M.; Maccarelli, F. Oenological properties of non-Saccharomyces yeasts associated with wine-making. World J. Microb. Biot. 1997, 14, 199-203. [CrossRef]

3. Granchi, L.; Ganucci, D.; Messini, A.; Vincenzini, M. Oenological properties of Hanseniaspora osmophila and Kloeckera cortices from wines produced by spontaneous fermentations of normal and dried grapes. FEMS Yeast Res. 2002, 2, 403-407. [CrossRef] [PubMed]

4. Loureiro, V.; Malfeito-Ferreira, M. Spoilage yeasts in the wine industry. Int. J. Food Microbiol. 2003, 86, 23-50. [CrossRef]

5. Lachance, M.A.; Gilbert, G.D.; Starmer, W.T. Yeast communities associated with Drosophila species and related flies in an eastern oak-pine forest: A comparison with western communities. J. Ind. Microbiol. 1995, 14, 484-494. [CrossRef] [PubMed]

6. Boundy-Mills, K.; Stratford, M.; Miller, M.W. Saccharomycodes E.C. Hansen (1904). In The Yeasts, a Taxonomic Study, 5th ed.; Kurtzman, C.P., Fell, J.W., Boekhout, T., Eds.; Elsevier: London, UK, 2011; pp. 747-750.

7. Malfeito-Ferreira, M.; Tareco, M.; Loureiro, V. Fatty acid profiling: A feasible typing system to trace yeast contamination in wine bottling plants. Int. J. Food Microbiol. 1997, 38, 143-155. [CrossRef]

8. Miller, M.W.; Phaff, H.J. Saccharomycodes E.C. Hansen. In The Yeasts. A Taxonomic Study, 4th ed.; Kurtzman, C.P., Fell, J.W., Eds.; Elsevier: New York, NY, USA, 1998; pp. 372-373.

9. Yamazaki, T.; Oshima, Y. Saccharomycodes ludwigii has seven chromosomes. Yeast 1996, 12, 237-240. [CrossRef]

10. Domizio, P.; Romani, C.; Lencioni, L.; Comitini, F.; Gobbi, M.; Mannazzu, I.; Ciani, M. Outlining a future for non-Saccharomyces yeasts: Selection of putative spoilage wine strains to be used in association with Saccharomyces cerevisiae for grape juice fermentation. Int. J. Food Microbiol. 2011, 147, 170-180. [CrossRef] [PubMed]

11. Romano, P.; Marchese, R.; Laurita, C.; Saleano, G.; Turbanti, L. Biotechnological suitability of Saccharomycodes ludwigii for fermented beverages. World J. Microb. Biot. 1999, 15, 451-454. [CrossRef]

12. Stratford, M.; Morgan, P.; Rose, A.H. Sulphur dioxide resistance in Saccharomyces cerevisiae and Saccharomycodes ludwigii. J. Gen. Microbiol. 1987, 133, 2173-2179. [CrossRef]

13. Thomas, D.S. Yeasts as spoilage organisms in beverages. In The yeasts. Yeast Technology, 2nd ed.; Rose, A.H., Harrison, J.S., Eds.; Academic Press: London, UK, 1993; Volume 5, pp. 517-561. ISBN 0-12-596415-3.

14. Warth, A.D. Resistance of yeast species to benzoic and sorbic acid and sulphur dioxide. J. Food Prot. 1985, 48, 564-569. [CrossRef]

15. Domizio, P.; Liu, Y.; Bisson, L.F.; Barile, D. Use of non-Saccharomyces wine yeasts as novel sources of mannoproteins in wine. Food Microbiol. 2014, 43, 5-15. [CrossRef] [PubMed]

16. Romano, P.; Fiore, C.; Paraggio, M.; Caruso, M.; Cepece, A. Function of yeast species and strains in wine flavour. Int. J. Food Microbiol. 2003, 86, 169-180. [CrossRef]

17. Fugelsang, K.C.; Edwards, C.G. Yeasts. In Wine Microbiology Practical Applications and Procedures, 2nd ed.; Fugelsang, K.C., Edwards, C.G., Eds.; Springer Science+Business Media: New York, NY, USA, 2007; pp. 3-14. ISBN 978-0-387-33349-6. 
18. Remize, F.; Roustan, J.L.; Sablayrolles, J.M.; Barre, P.; Dequin, S. Glycerol overproduction by engineered Saccharomyces cerevisiae wine yeast strains leads to substantial changes in byproduct formation and to a stimulation of fermentation rate in stationary phase. Appl. Environ. Microb. 1999, 65, 143-149.

19. Santos, A.; Marquina, D. Ion channel activity by Pichia membranifaciens killer toxin. Yeast 2004, 21, 151-162. [CrossRef] [PubMed]

20. Gschaedler, A. Contribution of non-conventional yeasts in alcoholic beverages. Curr. Opin. Food Sci. 2017, 13, 73-77. [CrossRef]

21. Costa, A.; Barata, A.; Malfeito-Ferreira, M.; Loureiro, V. Evaluation of the inhibitory effect of dimethyl dicarbonate (DMDC) against wine microorganisms. Food Microbiol. 2008, 25, 422-427. [CrossRef] [PubMed]

22. Roller, S.; Covill, N. The antifungal properties of chitosan in laboratory media and apple juice. Int. J. Food Microbiol. 1999, 47, 67-77. [CrossRef]

23. Lachance, M.A. Yeast communities in a natural tequila fermentation. Antonie van Leeuwenhoek 1995, 68, 151-160. [CrossRef] [PubMed]

24. Barnett, J.A.; Payne, R.W.; Yarrow, D. Yeasts: Characteristics and Identification, 3rd ed.; Cambridge University Press: Cambridge, UK, 2000.

25. Ogilvie, L. Observations on the "slime-fluxes" of trees. Trans. Br. Mycol. Soc. 1924, 9, 167-182. [CrossRef]

26. Stringini, M.; Comitini, F.; Taccari, M.; Ciani, M. Yeast diversity during tapping and fermentation of palm wine from Cameroon. Food Microbiol. 2009, 26, 415-420. [CrossRef] [PubMed]

27. Beech, F.W.; Carr, J.G. Cider and perry. In Economic Microbiology, Volume 1, Alcoholic beverages; Rose, A.H., Ed.; Academic Press: London, UK, 1977; pp. 139-313. ISBN 978-0125965507.

28. Morata, A.; Vejarano, R.; Ridolfi, G.; Benito, S.; Palomero, F.; Uthurry, C.; Tesfaye, W.; González, C.; Suárez-Lepe, J.A. Reduction of 4-ethylphenol production in red wines using HCDC+ yeasts and cinnamyl esterases. Enzyme Microb. Technol. 2013, 52, 99-104. [CrossRef] [PubMed]

29. Jarvis, B.; Lea, A.G.H. Sulphite binding in ciders. Int. J. Food Sci. Technol. 2000, 35, 113-127. [CrossRef]

30. OIV. Compendium of International Methods of Wine and Must Analysis, 2018 ed.; International Organization of Vine and Wine (OIV): Paris, France, 2018; Volume II, OIV-MA-C1-01: R2011; ISBN 979-10-91799-79-9. Available online: http:/ / www.oiv.int/public/medias/5773/compendium-2018-en-vol2.pdf (accessed on 25 July 2018).

31. Delfini, C.; Gaia, P.; Schellino, R.; Strano, M.; Pagliara, A.; Ambró, S. Fermentability of grape must after inhibition with dimethyl dicarbonate (DMDC). J. Agric. Food Chem. 2002, 50, 5605-5611. [CrossRef] [PubMed]

32. Santos, M.C.; Nunes, C.; Saraiva, J.A.; Coimbra, M.A. Chemical and physical methodologies for the replacement/reduction of sulfur dioxide use during winemaking: Review of their potentialities and limitations. Eur. Food Res. Technol. 2012, 234, 1-12. [CrossRef]

33. Vally, H.; Misso, N.L.A.; Madan, V. Clinical effects of sulphite additives. Clin. Exp. Allergy 2009, 39, $1643-1651$. [CrossRef] [PubMed]

34. Bech-Larsen, T.; Scholderer, J. Functional foods in Europe: Consumer research, market experiences and regulatory aspects. Trends Food Sci. Technol. 2007, 18, 231-234. [CrossRef]

35. Cravero, F.; Englezos, V.; Torchio, F.; Giacosa, S.; Río Segade, S.; Gerbi, V.; Rantsiou, K.; Rolle, L.; Cocolin, L. Post-harvest control of wine-grape mycobiota using electrolyzed water. Innov. Food Sci. Emerg. 2016, 35, 21-28. [CrossRef]

36. Hinze, H.; Holzer, H. Analysis of the energy metabolism after incubation of Saccharomyces cerevisiae with sulfite or nitrite. Arch. Microbiol. 1986, 145, 27-31. [CrossRef] [PubMed]

37. Stratford, M.; Rose, A.H. Transport of sulphide dioxide by Saccharomyces cerevisiae. J. Gen. Microbiol. 1986, 132, 1-6. [CrossRef]

38. Kaneko, H.; Hosahara, M.; Tanaka, M.; Itoh, T. Lipid composition of 30 species of yeast. Lipids 1976, 11, 837-844. [CrossRef] [PubMed]

39. Terrell, F.R.; Morris, J.R.; Johnson, M.G.; Gbur, E.E.; Makus, D.J. Yeast inhibition in grape juice containing sulfur dioxide, sorbic acid, and dimethyldicarbonate. J. Food. Sci. 1993, 58, 1132-1134. [CrossRef]

40. Threlfall, R.T.; Morris, J.R. Using dimethyldicarbonate to minimize sulfur dioxide for prevention of fermentation from excessive yeast contamination in juice and semi-sweet wine. J. Food Sci. 2002, 67, 2758-2762. [CrossRef]

41. Sawant, A.D.; Abdelal, A.T.; Ahearn, D.G. Purification and characterization of the anti-Candida toxin of Pichia anomala WC 65. Antimicrob. Agents Chemother. 1989, 33, 48-52. [CrossRef] [PubMed] 
42. Palpacelli, V.; Ciani, M.; Rosini, G. Activity of different 'killer' yeasts on strains of yeast species undesirable in the food industry. FEMS Microbiol. Lett. 1991, 84, 75-78. [CrossRef]

43. Oro, L.; Ciani, M.; Comitini, F. Antimicrobial activity of Metschnikowia pulcherrima on wine yeasts. J. Appl. Microbiol. 2014, 116, 1209-1217. [CrossRef] [PubMed]

44. Youssef, B.M.; Asker, A.A.; El-Samahy, S.K.; Swailam, H.M. Combined effect of steaming and gamma irradiation on the quality of mango pulp stored at refrigerated temperature. Food Res. Int. 2002, 35, 1-13. [CrossRef]

45. González-Arenzana, L.; Portua, J.; López, R.; López, N.; Santamaría, P.; Garde-Cerdán, T.; López-Alfaro, I. Inactivation of wine-associated microbiota by continuous pulsed electric field treatments. Innov. Food Sci. Emerg. 2015, 29, 187-192. [CrossRef]

46. OIV. International Code of Oenological Practices; Issue 2018; International Organization of Vine and Wine (OIV): Paris, France, 2018; OENO 5/01, OENO 421-2011; ISBN 979-10-91799-88-1.

47. Peterson, T.W.; Ough, C.S. Dimethyldicarbonate reaction with higher alcohols. Am. J. Enol. Viticult. 1979, 30, 119-123.

48. Suárez-Lepe, J.A.; Morata, A. New trends in yeast selection for winemaking. Trends Food Sci. Technol. 2012, 23, 39-50. [CrossRef]

49. Porter, L.T.; Ough, C.S. The effects of ethanol, temperature and dimethyldicarbonate on viability of Saccharomyces cerevisiae Montrachet No 522 in wine. Am. J. Enol. Viticult. 1982, 33, 222-225.

50. Divol, B.; Strehaiano, P.; Lonvaud-Funel, A. Effectiveness of dimethyldicarbonate to stop alcoholic fermentation in wine. Food Microbiol. 2005, 22, 169-178. [CrossRef]

51. Feng, M.; Lalor, B.; Hu, S.; Mei, J.; Huber, A.; Kidby, D.; Holbein, B. Inhibition of yeast growth in grape juice through removal of iron and other metals. Int. J. Food Sci. Technol. 1997, 32, 21-28. [CrossRef]

52. Jackson, S.L.; Heath, I.B. Roles of calcium ions in hyphal tip growth. Microbiol. Mol. Biol. R. 1993, 57, 367-382.

53. Fang, S.W.; Li, C.F.; Shih, D.Y.C. Antifungal activity of chitosan and its preservative effect on low-sugar candied kumquat. J. Food Protect. 1994, 56, 136-140. [CrossRef]

54. Leuba, J.L.; Stossel, P. Chitosan and other polyamines: Antifungal activity and interaction with biological membranes. In Chitin in Nature and Technology; Muzzarelli, R., Jeuniaux, C., Gooday, G.W., Eds.; Springer: Boston, MA, USA, 1986; pp. 215-222.

55. Muzzarelli, R.A.A. Chitosan-based dietary foods. Carbohydr. Polym. 1996, 29, 309-316. [CrossRef]

56. Ren, J.; Liu, J.; Li, R.; Dong, F.; Guo, Z. Antifungal properties of chitosan salts in laboratory media. J. Appl. Polym. Sci. 2012, 124, 2501-2507. [CrossRef]

57. Papineau, A.M.; Hoover, D.G.; Knorr, D.; Farkas, D.F. Antimicrobial effect of water-soluble chitosans with high hydrostatic pressure. Food Biotechnol. 1991, 5, 45-57. [CrossRef]

58. Schmitt, M.; Radler, F. Molecular structure of the cell wall receptor for killer toxin KT28 in Saccharomyces cerevisiae. J. Bacteriol. 1988, 170, 2192-2196. [CrossRef] [PubMed]

59. Saravanakumar, D.; Ciavorella, A.; Spadaro, D.; Garibaldi, A.; Gullino, M.L. Metschnikowia pulcherrima strain MACH1 outcompetes Botrytis cinerea, Alternaria alternata and Penicillium expansum in apples through iron depletion. Postharvest Biol. Technol. 2008, 49, 121-128. [CrossRef]

60. Combina, M.; Elia, A.; Mercado, L.; Catania, C.; Ganga, A.; Martinez, C. Dynamics of indigenous yeast populations during spontaneous fermentation of wine from Mendoza, Argentina. Int. J. Food Microbiol. 2005, 99, 237-243. [CrossRef] [PubMed]

61. Lopes, C.A.; Sangorrín, M.P. Optimization of killer assays for yeast selection protocols. Rev. Argent. Microbiol. 2010, 42, 298-306. [CrossRef] [PubMed]

62. Türkel, S.; Ener, B. Isolation and characterization of new Metschnikowia pulcherrima strains as producers of the antimicrobial pigment pulcherrimin. Z. Naturforsch. C 2009, 64, 405-410. [CrossRef] [PubMed]

63. Holmes-Hampton, G.P.; Jhurry, N.D.; McCormick, S.P.; Lindahl, P.A. Iron content of Saccharomyces cerevisiae cells grown under iron-deficient and iron-overload conditions. Biochemistry 2013, 52, 105-114. [CrossRef] [PubMed]

64. Comitini, F.; Gobbi, M.; Domizio, P.; Romani, C.; Lencioni, L.; Mannazzu, I.; Ciani, M. Selected non-Saccharomyces wine yeasts in controlled multistarter fermentations with Saccharomyces cerevisiae. Food Microbiol. 2011, 28, 873-882. [CrossRef] [PubMed] 
65. Mehlomakulu, N.N.; Setati, M.E.; Divol, B. Characterization of novel killer toxins secreted by wine-related non-Saccharomyces yeasts and their action on Brettanomyces spp. Int. J. Food Microbiol. 2014, 188, 83-91. [CrossRef] [PubMed]

66. Santos, A.; Navascués, E.; Bravo, E.; Marquina, D. Ustilago maydis killer toxin as a new tool for the biocontrol of the wine spoilage yeast Brettanomyces bruxellensis. Int. J. Food Microbiol. 2011, 145, 147-154. [CrossRef] [PubMed]

67. Santos, A.; Alonso, A.; Belda, I.; Marquina, D. Cell cycle arrest and apoptosis, two alternative mechanisms for PMKT2 killer activity. Fungal Genet. Biol. 2013, 50, 44-54. [CrossRef] [PubMed]

68. Alonso, A.; Belda, I.; Santos, A.; Navascués, E.; Marquina, D. Advances in the control of the spoilage caused by Zygosaccharomyces species on sweet wines and concentrated grape musts. Food Control. 2015, 51, 129-134. [CrossRef]

69. Berbegal, C.; Garofalo, C.; Russo, P.; Pati, S.; Capozzi, V.; Spano, G. Use of autochthonous yeasts and bacteria in order to control Brettanomyces bruxellensis in wine. Fermentation 2017, 3, 65. [CrossRef]

70. Morata, A.; Loira, I.; Vejarano, R.; González, C.; Callejo, M.J.; Suárez-Lepe, J.A. Emerging preservation technologies in grapes for winemaking. Trends Food Sci. Technol. 2017, 67, 36-43. [CrossRef]

71. Golberg, A. The impact of pulsed electric fields on cells and biomolecules: Comment on "Lightning-triggered electroporation and electrofusion as possible contributors to natural horizontal gene transfer" by Tadej Kotnik. Phys. Life Rev. 2013, 10, 382-383. [CrossRef] [PubMed]

72. Puértolas, E.; López, N.; Condón, S.; Raso, J.; Álvarez, I. Pulsed electric fields inactivation of wine spoilage yeast and bacteria. Int. J. Food Microbiol. 2009, 130, 49-55. [CrossRef] [PubMed]

73. Timmermans, R.; Nederhoff, A.; Groot, M.N.; van Boekel, M.; Mastwijk, H. Effect of electrical field strength applied by PEF processing and storage temperature on the outgrowth of yeasts and moulds naturally present in a fresh fruit smoothie. Int. J. Food Microbiol. 2016, 230, 21-30. [CrossRef] [PubMed]

74. Garde-Cerdán, T.; Arias-Gil, M.; Marsellés-Fontanet, A.R.; Ancín-Azpilicueta, C.; Martín-Belloso, O. Effects of thermal and non-thermal processing treatment on fatty acids and free amino acids of grape juice. Food Control 2007, 18, 473-479. [CrossRef]

75. Beveridge, J.R.; Wall, K.; MacGregor, S.J.; Anderson, J.G.; Rowan, N.J. Pulsed electric field inactivation of spoilage microorganisms in alcoholic beverages. In Proceedings of the 14th IEEE International Pulsed Power Conference, Dallas, TX, USA, 15-18 June 2003; pp. 1138-1143.

76. Milani, E.A.; Alkhafaji, S.; Silva, F.V.M. Pulsed electric field continuous pasteurization of different types of beers. Food Control 2015, 50, 223-229. [CrossRef]

77. Bely, M.; Stoeckle, P.; Masnuef-Pomarède, I.; Dubourdieu, D. Impact of mixed Torulaspora delbrueckii-Saccharomyces cerevisiae culture on high-sugar fermentation. Int. J. Food Microbiol. 2008, 122, 312-320. [CrossRef] [PubMed]

78. Bovo, B.; Carlot, M.; Lombardi, A.; Lomolino, G.; Lante, A.; Giacomini, A.; Corich, V. Exploring the use of Saccharomyces cerevisiae commercial strain and Saccharomycodes ludwigii natural isolate for grape marc fermentation to improve sensory properties of spirits. Food Microbiol. 2014, 41, 33-41. [CrossRef] [PubMed]

79. Fia, G.; Giovani, G.; Rosi, I. Study of beta-glucosidase production by wine-related yeasts during alcoholic fermentation. A new rapid fluorimetric method to determine enzymatic activity. J. Appl. Microbiol. 2005, 99, 509-517. [CrossRef] [PubMed]

80. Ugliano, M.; Bartowsky, E.J.; McCarthy, J.; Moio, L.; Henschke, P.A. Hydrolysis and transformation of grape glycosidically bound volatile compounds during fermentation with three Saccharomyces yeast strains. J. Agric. Food Chem. 2006, 54, 6322-6331. [CrossRef] [PubMed]

81. Wightman, J.D.; Wrolstad, R.E. $\beta$-glucosidase activity in juice-processing enzymes based on anthocyanin analysis. J. Food Sci. 1996, 61, 544-548. [CrossRef]

82. Vejarano, R.; Morata, A.; Loira, I.; González, M.C.; Suárez-Lepe, J.A. Theoretical considerations about usage of metabolic inhibitors as possible alternative to reduce alcohol content of wines from hot areas. Eur Food Res. Technol. 2013, 237, 281-290. [CrossRef]

83. Kulkarni, P.; Loira, I.; Morata, A.; Tesfaye, W.; González, M.C.; Suárez-Lepe, J.A. Use of non-Saccharomyces yeast strains coupled with ultrasound treatment as a novel technique to accelerate ageing on lees of red wines and its repercussion in sensorial parameters. LWT-Food Sci. Technol. 2015, 64, 1255-1262. [CrossRef]

84. Palomero, F.; Morata, A.; Benito, S.; Calderón, F.; Suárez-Lepe, J.A. New genera of yeasts for over-lees aging of red wine. Food Chem. 2009, 112, 432-441. [CrossRef] 
85. Giovani, G.; Rosi, I.; Bertuccioli, M. Quantification and characterization of cell wall polysaccharides released by non-Saccharomyces yeast strains during alcoholic fermentation. Int. J. Food Microbiol. 2012, 160, 113-118. [CrossRef] [PubMed]

86. Charpentier, C.; N'guyen Van Long, T.; Bonaly, R.C.; Feuillat, M. Alteration of cell wall structure in Saccharomyces cerevisiae and Saccharomyces bayanus during autolysis. Appl. Microbiol. Biotechnol. 1986, 24, 405-413. [CrossRef]

87. Klis, F.M.; Boorsma, A.; De Groot, P.W.J. Cell wall construction in Saccharomyces cerevisiae. Yeast 2006, 23, 185-202. [CrossRef] [PubMed]

88. Vidal, S.; Francis, L.; Williams, P.; Kwiatkowski, M.; Gawel, R.; Cheynier, V.; Waters, E. The mouth-feel properties of polysaccharides and anthocyanins in a wine like medium. Food Chem. 2004, 85, 519-525. [CrossRef]

89. Guadalupe, Z.; Palacios, A.; Ayestarán, B. Maceration enzymes and mannoproteins: A possible strategy to increase colloidal stability and color extraction in red wines. J. Agric. Food Chem 2007, 55, 4854-4862. [CrossRef] [PubMed]

90. Chalier, P.; Angot, B.; Delteil, D.; Doco, T.; Gunata, Z. Interactions between aroma compounds and whole mannoprotein isolated from Saccharomyces cerevisiae strains. Food Chem. 2007, 100, 22-30. [CrossRef]

91. Gonzalez-Ramos, D.; Cebollero, E.; Gonzalez, R. A recombinant Saccharomyces cerevisiae strain overproducing mannoproteins stabilizes wine against protein haze. Appl. Environ. Microbiol. 2008, 74, 5533-5540. [CrossRef] [PubMed]

92. Lubbers, S.; Léger, B.; Charpentier, C.; Feuillat, M. Effet colloïdes protecteurs d'extraits de parois de levures sur la stabilité tartrique d'un vin modèle. J. Int. Sci. Vigne. Vin. 1993, 27, 13-22.

93. Rodrigues, A.; Ricardo-Da-Silva, J.M.; Lucas, C.; Laureano, O. Effect of commercial mannoproteins on wine colour and tannins stability. Food Chem. 2012, 131, 907-914. [CrossRef]

94. Iriti, M.; Varoni, E.M. Cardioprotective effects of moderate red wine consumption: Polyphenols vs. Etanol. Review. J. Appl. Biomed. 2014, 12, 193-202. [CrossRef]

95. Loira, I.; Vejarano, R.; Morata, A.; Ricardo-da-Silva, J.M.; Laureano, O.; González, M.C.; Suárez-Lepe, J.A. Effect of Saccharomyces strains on the quality of red wines aged on lees. Food Chem. 2013, 139, 1044-1051. [CrossRef] [PubMed]

96. Rosi, I.; Gheri, A.; Domizio, P.; Fia, G. Production de macromolecules parietals de Saccharomyces cerevisiae au cours de la fermentation et leur influence sur la fermentation malolactique. Revue des CEnologues 2000, 94, 18-20.

97. Moreno-Arribas, V.; Pueyo, E.; Nieto, F.J.; Martín-Álvarez, P.J.; Polo, M.C. Influence of the polysaccharides and the nitrogen compounds on foaming properties of sparkling wines. Food Chem. 2000, 70, 309-317. [CrossRef]

98. Moruno, E.G.; Sanlorenzo, C.; Boccaccino, B.; Di Stefano, R. Treatment with yeast to reduce the concentration of ochratoxin A. in red wine. Am. J. Enol. Viticult. 2005, 56, 73-76.

99. Vejarano, R.; Siche, R.; Tesfaye, W. Evaluation of biological contaminants in foods by hyperspectral imaging (HSI): A. review. Int. J. Food Prop. 2017, 20, 1264-1297. [CrossRef]

100. Morata, A.; Gómez-Cordovés, M.C.; Suberviola, J.; Bartolomé, B.; Colomo, B.; Suárez-Lepe, J.A. Adsorption of anthocyanins by yeast cell walls during the fermentation of red wines. J. Agric. Food Chem. 2003, 51, 4084-4088. [CrossRef] [PubMed]

101. Morata, A.; Gómez-Cordovés, M.C.; Calderón, F.; Suárez-Lepe, J.A. Effects of pH, temperature and $\mathrm{SO}_{2}$ on the formation of pyranoanthocyanins during red wine fermentation with two species of Saccharomyces. Int. J. Food Microbiol. 2006, 106, 123-129. [CrossRef] [PubMed]

102. Rokhina, E.V.; Piet, L.; Virkutyte, J. Low-frequency ultrasound in biotechnology: State of the art. Trends Biotechnol. 2009, 27, 298-306. [CrossRef] [PubMed]

103. Koda, S.; Miyamoto, M.; Toma, M.; Matsuoka, T.; Maebayashi, M. Inactivation of Escherichia coli and Streptococcus mutants by ultrasound at $500 \mathrm{kHz}$. Ultrason. Sonochem. 2009, 16, 655-659. [CrossRef] [PubMed]

104. Zhou, C.; Ma, H. Ultrasonic degradation of polysaccharide from a red algae (Porphyra yezoensis). J. Agric. Food Chem. 2006, 54, 2223-2228. [CrossRef] [PubMed]

105. Liu, S.Q.; Aung, M.T.; Lee, P.R.; Yu, B. Yeast and volatile evolution in cider co-fermentation with Saccharomyces cerevisiae and Williopsis saturnus. Ann. Microbiol. 2016, 66, 307-315. [CrossRef] 
106. Lu, Y.; Huang, D.; Lee, P.R.; Liu, S.Q. Assessment of volatile and non-volatile compounds in durian wines fermented with four commercial non-Saccharomyces yeasts. J. Sci. Food Agric. 2016, 96, 1511-1521. [CrossRef] [PubMed]

107. Fugelsang, K. Population dynamics and effects of Brettanomyces bruxellensis strains on Pinot noir (Vitis vinifera L.) wines. Am. J. Enol. Viticult. 2003, 54, 294-300.

108. Crauwels, S.; Van Opstaele, F.; Jaskula-Goiris, B.; Steensels, J.; Verreth, C.; Bosmans, L.; Paulussen, C.; Herrera-Malaver, B.; de Jonge, R.; De Clippeleer, J.; et al. Fermentation assays reveal differences in sugar and (off-) flavor metabolism across different Brettanomyces bruxellensis strains. FEMS Yeast Res. 2017, 17, fow105. [CrossRef] [PubMed]

109. Smith, B.D.; Divol, B. Brettanomyces bruxellensis, a survivalist prepared for the wine apocalypse and other beverages. Food Microbiol. 2016, 59, 161-175. [CrossRef] [PubMed]

110. Nardi, T.; Remize, F.; Alexandre, H. Adaptation of yeasts Saccharomyces cerevisiae and Brettanomyces bruxellensis to winemaking conditions: A comparative study of stress genes expression. Appl. Microbiol. Biotechnol. 2010, 88, 925-937. [CrossRef] [PubMed]

111. Avramova, M.; Vallet-Courbin, A.; Maupeu, J.; Masneuf-Pomarede, I.; Albertin, W. Molecular diagnosis of Brettanomyces bruxellensis' sulfur dioxide sensitivity through genotype specific method. Front Microbiol. 2018, 9, 1260. [CrossRef] [PubMed]

112. Capozzi, V.; Di Toro, M.R.; Grieco, F.; Michelotti, V.; Salma, M.; Lamontanara, A.; Russo, P.; Orrù, L.; Alexandre, H.; Spano, G. Viable but not culturable (VBNC) state of Brettanomyces bruxellensis in wine: New insights on molecular basis of VBNC behaviour using a transcriptomic approach. Food Microbiol. 2016, 59, 196-204. [CrossRef] [PubMed]

113. Avramova, M.; Cibrario, A.; Peltier, E.; Coton, M.; Coton, E.; Schacherer, J.; Spano, G.; Capozzi, V.; Blaiotta, G.; Salin, F.; et al. Brettanomyces bruxellensis population survey reveals a diploid-triploid complex structured according to substrate of isolation and geographical distribution. Sci. Rep. 2018, 8, 4136. [CrossRef] [PubMed]

114. Guerrero, R.F.; Cantos-Villar, E. Demonstrating the efficiency of sulphur dioxide replacements in wine: A. parameter review. Trends Food Sci. Technol. 2015, 42, 27-43. [CrossRef]

115. Saldaña, G.; Puértolas, E.; Álvarez, I.; Meneses, N.; Knorr, D.; Raso, J. Evaluation of a static treatment chamber to investigate kinetics of microbial inactivation by pulsed electric fields at different temperatures at quasi-isothermal conditions. J. Food Eng. 2010, 100, 349-356. [CrossRef]

116. Marsellés-Fontanet, À.R.; Puig, A.; Olmos, P.; Mínguez-Sanz, S.; Martín-Belloso, O. Optimising the inactivation of grape juice spoilage organisms by pulse electric fields. Int. J. Food Microbiol. 2009, 130, 159-165. [CrossRef] [PubMed]

117. Portugal, C.; Sáenz, Y.; Rojo-Bezares, B.; Zarazaga, M.; Torres, C.; Cacho, J.; Ruiz-Larrea, F. Brettanomyces susceptibility to antimicrobial agents used in winemaking: In vitro and practical approaches. Eur. Food Res. Technol. 2014, 238, 641-652. [CrossRef]

118. Bizri, J.N.; Wahem, I.A. Citric acid and antimicrobial affect microbiological stability and quality of tomato juice. J. Food Sci. 1994, 59, 130-134. [CrossRef]

119. Barceloux, D.G.; Bond, G.R.; Krenzelok, E.P.; Cooper, H.; Vale, J.A. American Academy of Clinical Toxicology practice guidelines on treatment of methanol poisoning. J. Toxicol. Clin. Toxicol. 2002, 40, 415-446. [CrossRef] [PubMed]

120. Cravero, F.; Englezos, V.; Rantsiou, K.; Torchio, F.; Giacosa, S.; Río Segade, S.; Gerbi, V.; Rolle, L.; Cocolin, L. Control of Brettanomyces bruxellensis on wine grapes by post-harvest treatments with electrolyzed water, ozonated water and gaseous ozone. Innov. Food Sci. Emerg. Technol. 2018, 47, 309-316. [CrossRef]

121. Charpentier, C.; Escot, S.; González, E.; Dulau, L.; Feuillat, M. The influence of yeast glycosylated proteins on tannins aggregation in model solution. Int. J. Vine Wine Sci. 2004, 38, 209-218. [CrossRef]

122. Suárez-Lepe, J.A.; Morata, A. Nuevo Método de Crianza Sobre Lías. Patente P200602423, 25 September 2006.

(C) 2018 by the author. Licensee MDPI, Basel, Switzerland. This article is an open access article distributed under the terms and conditions of the Creative Commons Attribution (CC BY) license (http://creativecommons.org/licenses/by/4.0/). 